\title{
Current Approaches to Discover Marine Antileishmanial Natural Products
}

Authors

Affiliations
André G. Tempone ${ }^{1}$, Camila Martins de Oliveira ${ }^{2}$, Roberto G. S. Berlinck ${ }^{2}$

${ }^{1}$ Department of Parasitology, Laboratory of Applied Toxinology on Anti-parasitic Drugs, Instituto Adolfo Lutz, São Paulo, SP, Brazil

2 Department of Physical Chemistry, Instituto de Química de São Carlos, Universidade de São Paulo, São Carlos, SP, Brazil

Key words
leishmaniasis
drug
therapy
marine natural products
in vitro bioassays
Leishmania

received July 14,2010 revised Nov. 22, 2010 accepted Dec. 2, 2010

\section{Bibliography}

Dol http://dx.doi.org/ 10.1055/s-0030-1250663 Published online January 17 , 2011

Planta Med 2011; 77: 572-585 (c) Georg Thieme Verlag KG Stuttgart · New York . ISSN 0032-0943

\section{Correspondence}

André G. Tempone

Department of Parasitology Laboratory

of Applied Toxinology on Anti-parasitic Drugs Instituto Adolfo Lutz

Avenida Dr. Arnaldo, 351, $8^{\circ}$ andar

Cerqueira Cesar

CEP 01246-000 - São Paulo/SP Brazil

Phone: + 551130682991

Fax: + 551130682890

atempone@ial.sp.gov.br

\section{Abstract \\ $\nabla$}

Leishmaniasis is a neglected infectious disease caused by kinetoplastid protozoans. An urgent need for novel chemotherapeutics exists. The current approaches to discover new antileishmanial compounds present many drawbacks, including high-cost and time-consuming bioassays. Thus, advances in leishmaniasis treatment are limited, and the development of screening assays is hindered. The combination of multidisciplinary approaches using standardised methods and syn-

\section{Introduction}

Leishmaniasis is an infectious disease caused by a protozoan parasite endemic to tropical and subtropical countries. This disease primarily affects poor populations and is estimated to affect 12 million people worldwide [1]. Leishmaniasis consists of four primary clinical syndromes: cutaneous leishmaniasis, mucocutaneous leishmaniasis (also known as espundia), visceral leishmaniasis (VL; also known as kala-azar), and diffuse leishmaniasis. Although cutaneous leishmaniasis may lead to disfigurement, only VL is considered a fatal disease [2]. VL affects approximately 500000 people worldwide and has a high mortality rate of 59000 deaths per year [3]. This disease is caused by the Leishmania (L.) donovani complex in East Africa and the Indian subcontinent, by Leishmania (L.) infantum in Europe, North Africa, and Latin America $[4,5]$ and by $L$. (L.) chagasi in Brazil [6]. The incidence of Leishmania spp. and HIV coinfection continues to rise in many countries; coinfection results in a poor prognosis for $\mathrm{VL}$ patients as a consequence of the difficult diagnosis and reduced responsiveness to treatment [7].

Leishmaniasis, a vector-born disease, is caused by obligate intramacrophage parasites. Leishmania chronous projects could be an alternative to develop novel drugs for leishmaniasis treatment. In this review, we discuss the current status of leishmaniasis occurrence and treatment. In addition, we address the advantages and limitations of in vitro leishmaniasis bioassays and discuss the findings of drug discovery research using natural products. Finally, we comprehensively review the marine natural products that are active against Leishmania spp., including their natural sources and bioactivity profile. 
Despite the introduction of the less toxic liposomal formulation of amphotericin B, Ambisome, therapeutic use is limited in undeveloped countries due to high costs. In Brazil, the liposomal formulation is provided as a first-line treatment for young children, HIV-coinfected patients, and old people and only in the São Paulo state.

Pentamidine is used as a second-line treatment for leishmaniasis; however, it can cause irreversible insulin-dependent diabetes mellitus and death. In addition to its severe toxic effects, pentamidine has poor efficacy, resulting in the abandonment of this treatment in India [13].

The use of "piggy-back" chemotherapy has led to the discovery of the use of the anticancer drug miltefosine for the treatment of Leishmania spp. parasites. This is the first effective orally dosed drug for VL [14]. Combination therapy for VL has increasingly been advocated as a way to increase treatment efficacy and tolerance, reduce treatment duration and cost, and limit the emergence of drug resistance [15]. A phase 2, non-comparative randomised trial performed in India assessed different combinations of a single dose of liposomal amphotericin B followed by miltefosine for 7-14 days, resulting in a highly efficacious (more than $95 \%$ of patients cured) treatment [16]. Despite the efficacy of miltefosine, its adverse effects include severe gastrointestinal toxicity and significant increases in the levels of serum aspartate aminotransferase, alanine aminotransferase, and creatinine [17]. In addition, orally dosed miltefosine for the treatment of Indian kala-azar failed to treat the American species $L$. (L.) mexicana and $L$. (V.) braziliensis [18].

Azoles and allopurinol are two of several oral drugs that are weakly active against Leishmania. These drugs are not useful as a single agent, and case reports record the effective treatment of immunosuppressed patients when the drugs were used in combination [19]; however, clinical trials to test this combination have not been performed.

The aminoglycoside antibiotic paromomycin has entered clinical studies and displays antileishmanial activity in India [20], albeit with a significant increase ( $>5$-fold) in hepatic transaminases [21]. Paromomycin is a potential new candidate; however, treatment failure and relapse occur when it is used as a monotherapy. Sitamaquine is an oral 8 -aminoquinoline analogue that has shown some efficacy to treat VL more than 20 years. This drug is being developed by GlaxoSmithKline (GSK), and marketing for the drug has been delayed [22]. Phase II studies were conducted in Brazil [23] and India [24] with cure rates ranging from $27 \%$ to $87 \%$; however, there were several cases of serious adverse renal events.

In addition to specific antileishmanial drugs, other coinfections also need to be attended. Because the majority of the population affected by leishmaniasis is poor, a major therapeutic concern is to manage anaemia and malnutrition to ensure the antileishmanial drugs remain effective. In Brazil, concomitant parasitic infections are frequently observed in patients from areas endemic with leishmaniasis, resulting in a challenge when one considers which disease should be treated first. Moreover, the use of a single drug to treat every Leishmania species is unrealistic. Even in the same country, Leishmania spp. strains vary in terms of sensitivity to antimonial therapy [25]. In practice, no definitive therapeutic protocol is followed in Brazil as a result of different social realities, patients, nutritional states, and infection by different Leishmania species and strains.

\section{Differences in Drug Discovery Approaches Using Natural Products \\ $\nabla$}

The development of simple, reliable, and rapid tests to screen large chemical libraries for novel antileishmanial agents is a goal for drug discovery groups. In general, most assays are time consuming and faster methodologies require sophisticated instruments; however, these are cost prohibitive for most laboratories in developing countries. Furthermore, the determination of drug activity at the mammalian stage (intracellular amastigotes) is indispensable and requires intense experimental manipulation over many days. Finally, the evaluation of new drug candidates requires in vivo assays and also demands time-consuming investigations, ranging from some days to several months.

Standardisation of drug discovery assays has been a difficult task, especially when one considers the multidisciplinary research involved in the process. The ineffective interaction between chemists and biologists is the first major limitation for the development of new lead compounds. An increasing number of reports describe the antileishmanial activity of natural products [2629], including marine invertebrate metabolites [30]. Few of these compounds have been evaluated for in vitro selectivity or in vivo. In addition, only small amounts of compounds can be isolated from marine animals. Thus, adequate amounts of compound must be synthesised for the complementary assays.

Only one compound from a library of 5000 to 10000 compounds has reached the market. Thus, a major limitation for drug development is the lack of a suitable chemical library. Increased chemical diversity can be obtained by combinatorial chemistry using natural compounds as prototypes. Effective interaction between research groups is also essential for the rapid synthesis of novel selective compounds and would provide a greater chance for lead development from natural products.

\section{Lack in Consensus on Natural Product Research for the Discovery of Antileishmanial Agents} $\nabla$

Oftentimes, when multidisciplinary groups are involved in drug discovery efforts using natural products, a consensus in methodology and protocols is difficult to obtain. Some major concerns are presented in the following subsections.

\section{Biological testing of crude extracts or}

pre-fractionated samples for screening purposes

Natural products must be made into extracts for drug screening purposes. However, in vitro testing of crude extracts may result in false-negative results. Rapid fractionation using liquid-liquid partitioning or simple chromatographic techniques, such as solid-phase extraction, may avoid these problems by enriching for active compounds in specific fractions and eliminating inactive metabolites. In particular, for marine invertebrate metabolites, pre-fractionation of crude extracts is an effective way to eliminate undesirable salts and polar primary metabolites.

\section{What solvents are suitable for microplate assays?}

Despite a few hydrophilic secondary metabolites, most natural compounds are solubilised in an organic solvent before in vitro evaluation. The use of polar solvents to dissolve these compounds results in an inaccurate concentration, leading to unreliable results. Therefore, test compounds could also be added directly to the microplate wells and dried in situ before the incubation with 
parasites. Most 96-well microplates are composed of polystyrene and do not support organic solvents. Furthermore, a large amount of organic solvents interfere with spectrophotometer readers. Thus, plates composed of polypropylene may be used as an alternative. However, in practice, dimethylsulfoxide (DMSO), ethanol (EtOH), and methanol $(\mathrm{MeOH})$ are the most frequently used solvents, and these do not interfere with the spectrophotometer. However, the simultaneous dilution of sample in organic solvents and incubation with parasites is a common practice. Regarding Leishmania parasites and macrophages, $0.5 \%$ of $\mathrm{MeOH}$ or DMSO as a maximum final concentration is recommended to avoid toxicity and false-positives.

\section{Testing concentrations}

Choosing an appropriate compound concentration is important to avoid missing active compounds and erroneous interpretation of data. For crude and pre-fractionated extracts, it is important to consider that the active compound(s) might be in a very modest quantity. For example, if a tested extract is incubated at $10 \mu \mathrm{g} / \mathrm{mL}$ and the active compound represents only $0.1 \%$ of the crude extract mass, this substance will induce antiparasitic activity at $0.01 \mu \mathrm{g} / \mathrm{mL}$, which is, in practice, an unusual event. On the contrary, if the extract is tested at elevated concentrations (>300 $\mathrm{gg} / \mathrm{mL}$ ), the insoluble material on the bottom of the microplate will most likely interfere with microscopic analysis and the colorimetric or fluorimetric viability tests. An additional drawback of using elevated compound concentrations is the false selection of poorly active molecules (50\% effective concentration higher than $100 \mu \mathrm{g} / \mathrm{mL}$ ). Based on previous research, fractionated samples should not be tested at concentrations higher than $300 \mu \mathrm{g} / \mathrm{mL}$, and the concentration of isolated substances should be limited to $100 \mu \mathrm{g} / \mathrm{mL}$. However, structural modification of weakly active compounds may improve efficacy.

\section{Current In Vitro Screening Assays}

$\nabla$

\section{Classical methods}

Axenic parasites: The use of axenic promastigotes or amastigotes is a low-cost alternative for screening large secondary metabolite libraries [18]. Promastigotes are the extracellular form of parasites and live in the gut of the sand fly insect. The ease of parasite maintenance in culture and assay performance allows for screening of hundreds of compounds using unsophisticated equipments. Briefly, promastigotes are counted using a hemocytometer and a light microscope and then incubated with test compounds in 96-well microplates for 24 to $96 \mathrm{~h}$. Classical methods, such as direct counting assays using a hemocytometer, are still in use in many laboratories; however, this technique is time consuming and only tests growth inhibition, not leishmanicidal activity. The major disadvantages of this assay are the daily timeconsuming cell counting and the potential of inaccurate $50 \%$ effective concentration $\left(\mathrm{EC}_{50}\right)$ values.

The MTT colourimetric test is a precise and low-cost viability assay [31] that is analysed using a microplate spectrophotometer. This method is based on the oxidative activity of mitochondria and provides additional information about whether a compound has leishmanicidal activity. This test can be used to optimise the screening of large libraries with high reproducibility and accurate determination of $\mathrm{EC}_{50}$ values. A major advantage of this assay is the ease of obtaining $\mathrm{EC}_{50}$ curves, which can be determined after a 24 -h incubation with the parasite followed by a 4 -h incu- bation with the MTT substrate. A major disadvantage of the assay is the possible oxidation of the MTT substrate by the test compounds, resulting in false-negatives [32,33]. The presence of a purple formazan colour is indicative of viable parasites and is lost upon cell death. A fast plate centrifugation step can be included to extract the test compound from the media before MTT addition. Care should be taken to avoid additional errors during plate manipulation. In addition, observation under a light microscope should be performed prior to the addition of the MTT substrate to evaluate parasite motility and morphology.

An alternative to the colourimetric MTT assay is the oxidation-reduction indicator Alamar Blue. This dye has been developed to assess the antileishmanial activity of drug candidates. After incubation of Alamar Blue with samples (crude extracts, enriched fractions or pure compounds), promastigote viability is determined at $570 \mathrm{~nm}$ in a microplate reader [34].

The use of axenic amastigotes for compound screening presents some advantages. This test is performed with a clinically relevant stage of the parasite. In addition, quantification of drug activity is very feasible. This is achieved with a cell counter [35], evaluating cell viability using an MTT-based method [31], determining ornithine decarboxylase activity [36], or labelling with a fluorescent dye, such as propidium iodide, followed by fluorescence activated cell sorter (FACS) analysis [37,38]. However, certain biochemical and immunological markers of the axenic amastigotes must be confirmed and a high concentration of serum is required in some systems. Differences in drug sensitivity between axenic $L$. donovani amastigotes and intracellular amastigotes have been observed [18]. As a general rule, the lack of an effect on macrophages results in free access of the parasites to drug and consequently, a high number of active compounds are determined. Because Leishmania is an intracellular pathogen, the use of an intracellular assay to confirm effects is recommended.

Intracellular assay: Because promastigotes are significantly more susceptible to drug-induced effects than amastigotes, tests using promastigotes must be considered as preliminary. Use of an additional intracellular assay will provide the most relevant information about the compound efficacy [39]. This is also a time-consuming assay, as initial cytotoxicity evaluation of the test samples is mandatory to avoid the use of high sample concentrations, which could harm macrophages. Many mammalian cells have been used to host Leishmania amastigotes, including mouse peritoneal macrophages, bone marrow-derived macrophages, peripheral blood monocyte-derived macrophages, and the tumour monocyte-derived macrophage THP-1, resulting in very significant variations in drug susceptibility [40]. Data from our lab and from the literature have indicated that mouse peritoneal macrophages are the most accurate model, providing reproducible results after $96-120 \mathrm{~h}$ and an elevated ratio of infection (>90\%), which is essential for an accurate analysis.

Amastigotes are appropriate parasites for in vitro macrophage infection. Although promastigotes can be used to infect macrophages as an alternative, the maintenance of parasites inside the host cell for an adequate period ( 96 to $120 \mathrm{~h}$ ) is not possible with most Leishmania species. This is a result of the effective macrophage elimination of promastigotes by oxidative mechanisms [41]. Amastigotes are best for in vitro infection, as the penetration into macrophages is "noiseless". This may be attributed to an elevated level of phosphatidylserine [42], leading to the expression of anti-inflammatory cytokines, such as TGF- $\beta$ [43]. Furthermore, amastigotes can resist reactive oxygen species from the host cell by increasing the expression of protective antioxidant enzymes 
[44]. Thus, the use of amastigotes is highly recommended for macrophage infections. However, this is somewhat time consuming since the amastigotes must be isolated from infected animals. Alternatively, amastigotes may be obtained by in vitro transformation of promastigotes with minimal changes to the growth conditions and temperature [45]. This method provides effective drug susceptibility assays with persistent infection in macrophages.

After drug testing (96 to $120 \mathrm{~h}$ ), slides are fixed with methanol and stained with Giemsa for microscopic observation (1000× magnification; oil immersion). Drug efficacy is determined by scoring the mean reduction in the parasitic index $(\mathrm{PI}=$ mean number of infected cells $\times$ mean number of amastigotes per macrophage) out of 500 macrophages.

\section{Other methods}

Reporter gene technology: Reporter genes are used to create modified parasites with a readily measurable phenotype that can be easily distinguished. The use of reporter genes to monitor intracellular microorganism proliferation has been effectively used for bacteria $[46,47]$ and other parasites $[48,49]$. Such methods produce objective quantitative data, high throughput, and require minimal manual labour. A variety of reporter genes have been effectively used in biological screenings, including firefly luciferase, green fluorescent protein (GFP), $\beta$-galactosidase, $\beta$-lactamase, chloramphenicol acetyltransferase (CAT), and alkaline phosphatase [50]. These reporters facilitate sample screening with high sensitivity.

The firefly luciferase gene is a common reporter gene that catalyses the reaction of luciferin with adenosine triphosphate (ATP) to generate photons. The biochemical output can be used to access the transcriptional activity in cells and to measure the cellular ATP level in a cell viability assay [51]. A recombinant $L$. (L.) amazonensis that expresses the firefly luciferase gene has been developed [51], allowing the observation of parasitism in real time in live animals. Luciferase activity, which is derived from a standard curve established with purified amastigotes, is measured to determine the parasite burden in macrophages or in mouse tissues. The major disadvantages of this assay are the high cost of the luciferin substrate and the short half-life of gene expression [52]. Green fluorescent protein (GFP) allows imaging and quantification of parasites using a fluorimeter [53,54], a fluorescence microscope, or by fluorescent activated cell sorter (FACS) analysis [51]. Transgenic $L$. (L.) donovani expressing GFP has been developed and can be expressed in promastigotes and amastigotes for approximately one year without drug pressure. Thus, screening of drug candidates by FACS analysis can be performed [55]. The major disadvantages of this assay are the need for post-translational modifications and low sensitivity [52].

Colourimetric assays to detect protein expression are also promising techniques for drug screening with promastigotes and intracellular amastigotes. Promastigotes of Leishmania that express $\beta$-galactosidase [56] can be used for colourimetric detection. However, some of the drawbacks of the $\beta$-galactosidase assay include its large size (the monomer is $116 \mathrm{kDa}$ ) and the endogenous expression of this protein by some mammalian cell types, including macrophages, preventing the use of these cells for drug screening [57]. Buckner and Wilson [58] reported the use of a $\beta$ lactamase reporter gene to quantify $L$. (L.) major and $L$. (L.) amazonensis amastigotes in macrophages in a 96-well format. The $\beta$ lactamase gene was integrated into an rRNA region of the genome, allowing for stable expression of the enzyme $[59,60]$. Pre- viously, Leishmania parasites were quantified and large sample libraries were screened using a spectrophotometer and a colourimetric nitrocefin reaction [58]. Ideal expression stability was determined by passing the parasites through mice.

However, the use of fluorescent markers or enzymes for the screening of large libraries has many drawbacks. Typically, transfected parasites do not express a sufficient amount of fluorescent protein for microplate reader evaluation and thus require the use of FACS analysis, which decreases the throughput. In addition, the current status of reporter gene technology is far from ideal conditions. Reporters are not inert and may affect parasite or host physiology. Furthermore, the use of sophisticated and expensive equipment, such as a FACS sorter, luminometers, and spectrofluorometers, limits the use of these tests, especially in developing countries.

Flow cytometry: Flow cytometry is commonly used for diagnostics; however, it is also a useful tool for screening drug candidates against Leishmania [61]. Leishmania promastigote viability can easily be assessed by SYBR-14, a membrane-permeable nuclear stain, in combination with propidium iodide (PI), a nucleic acid dye that is unable to penetrate intact living cells [62]. Alternatively, Leishmania promastigote viability can be quantified by measuring cell division using 5,6-carboxyfluorescein diacetate succinimidyl ester (CFSE) staining [61]. Transgenic Leishmania that express fluorescent reporter proteins, such as GFP, require a flow cytometry (FACS)-based method to assess parasite viability [41].

Sample screening can be satisfactorily performed using stained Leishmania promastigotes to infect macrophages in combination with a fluorescent marker, such as 2',7'-bis-(2-carboxyethyl)-5 (6)-carboxyfluorescein acetoxymethyl ester (BCECF-Am), SYTO 17, and PKH2-GL, followed by flow cytometry; however, this method requires drug incubation periods no longer than 1 day [63]. Though this technique can be used for amphotericin $B$, it is not suitable for screening compounds that require a 96- to 120 -h incubation time.

Radioactive nucleotides: The incorporation of ${ }^{3}[\mathrm{H}]$ thymidine to assess Leishmania growth has been used since 1977 [64]. The technique was also used for drug discovery to evaluate Leishmania promastigote viability [65]. Despite its high sensitivity, this test has been less popular in recent years because of the generation of radioactive waste and low throughput.

Acid phosphatase activity: Assays based on the enzymatic hydrolysis of p-nitrophenyl-phosphate are an alternative method for the spectrophotometric determination of Leishmania promastigote survival [66]. This assay is simple, inexpensive, and highly reproducible, but its use in literature is very limited.

Therapeutic targets in leishmania and high-throughput screening (HTS): HTS is a well-established process to screen large chemical libraries against biological targets via the use of automation, miniaturised assays, and large-scale data analysis. This is widely used by pharmaceutical companies and, to a lesser extent, by academic researchers, to meet the demand for faster screening of small molecule libraries, which are based on genomics or combinatorial chemistry [67]. Initially, HTS studies were performed with a library composed of 50000 to 350000 compounds in a 96-well microplate format. Currently, most screening projects are performed with 500000 to 1500000 compounds using 1536-well plates in an ultra-HTS system. Thus, this assay requires selective and validated biochemical targets as well as a large number of compounds. However, the majority of targets in an HTS-based lead discovery using mammalian cells fall into a modest set of tar- 
get families, such as kinases, proteases, phosphatises, oxidoreductases, phosphodiesterases, and transferases [68].

Unfortunately, only a small number of potential HTS targets have been validated for leishmaniasis. These include trypanothione metabolism, cysteine peptidases, sterol biosynthesis (14- $\alpha$-demethylase), dihydrofolate reductases, polyamine metabolism (ornithine decarboxylase), and tubulin [69]. The lack of genetic or chemical validation of novel targets and the difficulty of obtaining large libraries for the discovery of novel inhibitory compounds limits the improvement of HTS-based screening against Leishmania. However, a recent study screened 80000 compounds using Leishmania GDP-mannose phosphorylase as a readout, resulting in twenty selective nontoxic candidates. These compounds were also active in vitro against intracellular amastigotes [70].

\section{Complementary assays - the selectivity index (SI)}

For proper drug evaluation, it is good practice to evaluate in vitro cytotoxicity in mammalian cells. The correlation between in vitro cytotoxicity and antiparasitic activity $\left(\mathrm{EC}_{50}\right.$ against mammalian cells/EC 50 against Leishmania) is given by the selectivity index (SI). The $\mathrm{EC}_{50}$ value for test compounds is determined by treating one or a panel of mammalian cells with a serial dilution of the compound. A candidate compound must have an SI higher than 1 , otherwise the compound is more toxic in mammalian cells than in Leishmania. In particular, for antileishmanial assays, the use of macrophages is recommended in order to determine the highest drug concentrations for the intracellular assay. One should consider that SI is a prediction of in vitro toxicity, and a large panel of cells must be tested to assess in vitro efficacy of the candidate compound.

\section{Marine Organisms as a Source of Antileishmanial Compounds $\nabla$}

During the past 60 years, marine organisms have been investigated as a source of structurally unique and biologically active secondary metabolites [71]. The discovery of the first antiparasitic marine natural product in the late 1980s gained the attention of several research groups around the world, and marine secondary metabolites are now being evaluated as drug leads for treatment of neglected diseases, such as malaria, Chagas disease, and leishmaniasis. Currently, there are numerous academic initiatives to discover antiparasitic marine natural products from specific organisms, such as cyanobacteria, or in specific geographical regions, such as in Central America, New Zealand, and South America. Other research programs have also significantly contributed to the discovery of antileishmanial marine natural products. The findings of these groups are comprehensively summarised and discussed in the following sections.

\section{Peptides ( $\odot$ Figs. 1 and 2 )}

The marine cyanobacterium Lyngbya majuscula is an outstanding source of biologically active and structurally unique secondary metabolites. A strain of $L$. majuscula isolated from mangrove roots yielded a crude extract that displayed strong in vitro antileishmanial activity against $L$. (L.) donovani amastigotes. Chromatographic separation of this crude extract yielded the $\mathrm{N}$-methylated linear lipopeptide, almiramide A-C (1-3). Biological evaluation of these three peptides showed that almiramide B (2) and C (3) display strong in vitro antiparasitic activity against $L$. (L.) donovani amastigotes $\left(\mathrm{EC}_{50}=2.4\right.$ and $1.9 \mu \mathrm{M}$ for 2 and 3, respectively) and weak cytotoxicity in mammalian Vero cells (52.3 and 33.1 $\mu \mathrm{M}$ for $\mathbf{2}$ and 3, respectively). Almiramide A (1) was inactive up to $13.5 \mu \mathrm{M}[72]$.

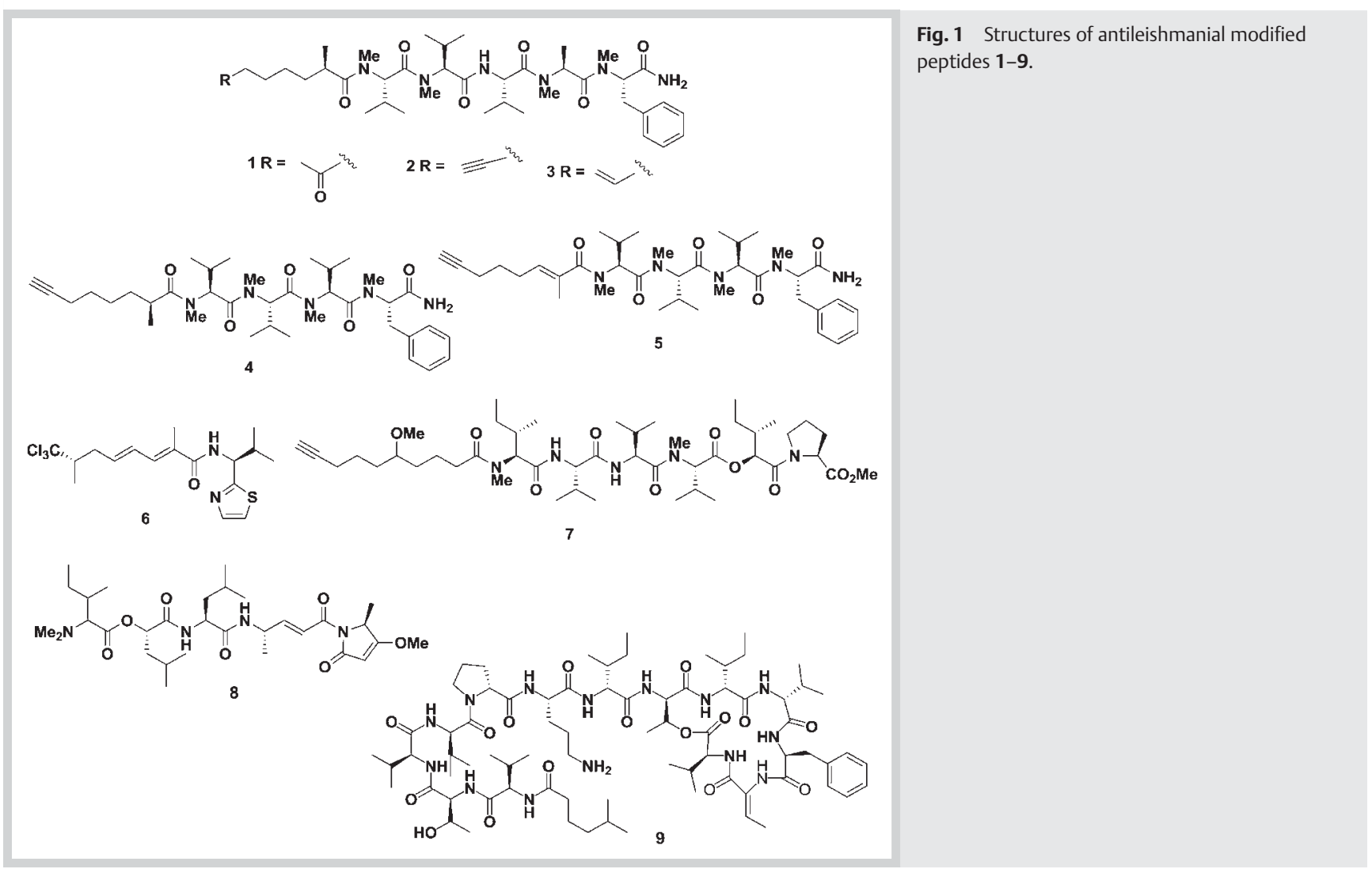




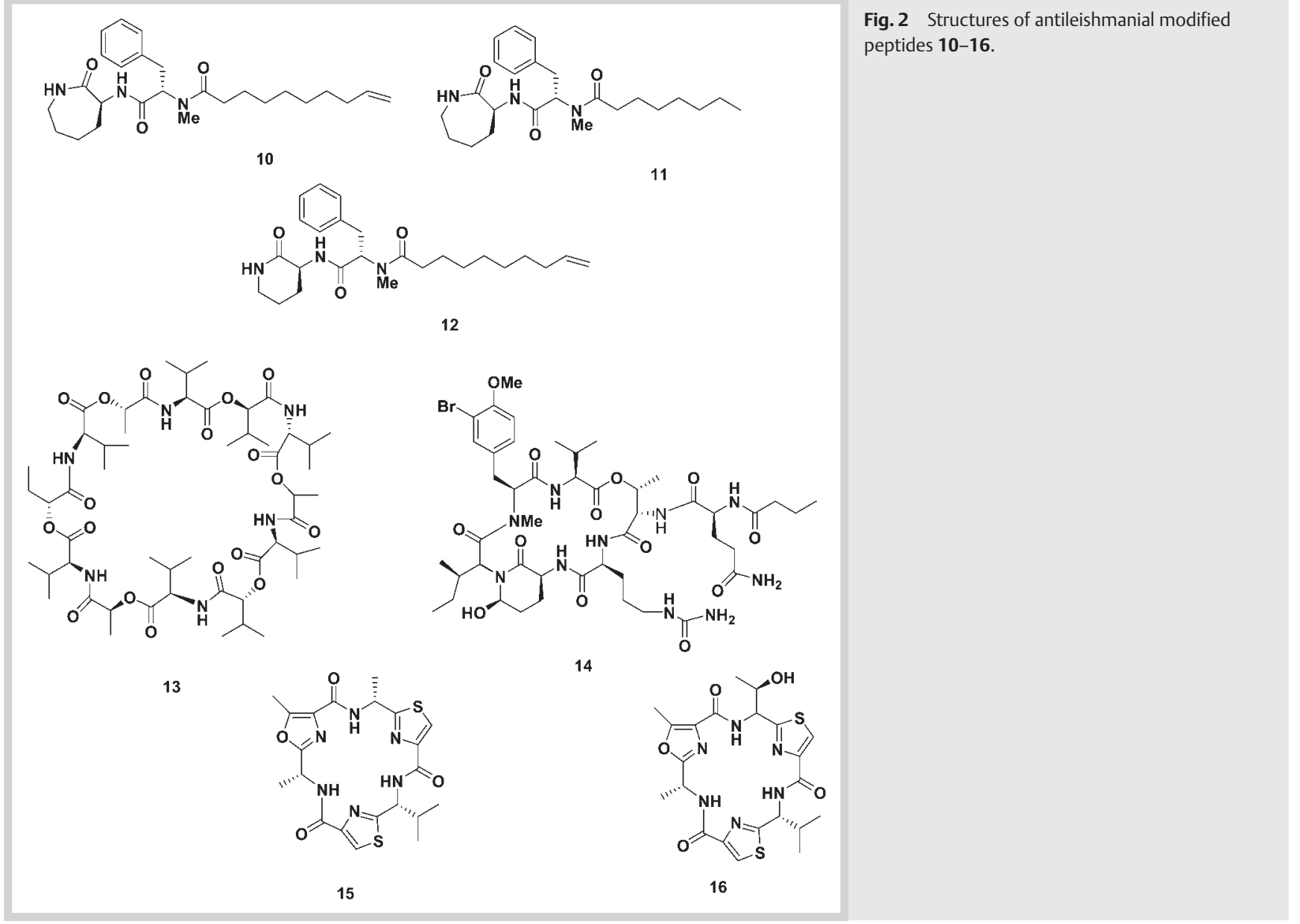

Dragonamide A (4), E (5), and herbamide B (6) were also isolated from Lyngbya majuscula and displayed comparable in vitro activity against $L$. (L.) donovani (axenic amastigotes) $\left(\mathrm{EC}_{50}=6.5,5.1\right.$, and $5.9 \mu \mathrm{M}$, respectively) [73].

Viridamide A (7) isolated from Oscillatoria nigro-viridis displayed antiparasitic activity against $L$. (L.) mexicana amastigotes as assessed by a DNA fluorescence method. In addition, viridamide A (7) showed antileishmanial activity with an $\mathrm{EC}_{50}$ of $1.5 \mu \mathrm{M}$ [74]. Bioassay-guided fractionation of organic extracts from the cyanobacteria Schizothrix sp. led to the isolation of a highly functionalised linear peptide, gallinamide A. Gallinamide A (8) was tested against Leishmania (L.) donovani promastigotes and displayed antiparasitic activity at $\mathrm{EC}_{50} 9.3 \mu \mathrm{M}$. It also displayed moderate cytotoxicity in Vero cells $\left(\mathrm{EC}_{50}=10.4 \mu \mathrm{M}\right)$ and in vitro cytotoxicity in $\mathrm{NCI}-\mathrm{H} 460$ human lung tumour and neuro-2a mouse neuroblastoma cell lines up to $16.9 \mu \mathrm{M}$ [75].

Kahalalide $\mathrm{F}(\mathbf{9})$ is a cyclic depsipeptide derived from the Hawaiian herbivorous marine mollusc Elysia rufescens. Kahalalide F (9) was tested for its activity and plausible mode of action against Leishmania promastigotes (L. [L.] donovani and L. [L.] pifanoi) and amastigotes (L. [L.] pifanoi). In general, amastigotes were more resistant than promastigotes. Kahalalide F inhibited $L$. (L.) donovani and $L$. (L.) pifanoi at concentrations of $6.13 \mu \mathrm{M}$ and $8.31 \mu \mathrm{M}$, respectively, and the amastigotes of $L$. (L.) pifanoi at $29.53 \mu \mathrm{M}$. Compound 9 also showed cytotoxic activity against peritoneal macrophages $(10.23 \mu \mathrm{M})$ and bovine aortic endothelial cells $(25.8 \mu \mathrm{M})$ [76].
Ciliatamides A-C (10-12) isolated from the deep sea sponge Aaptos ciliata were evaluated for antileishmanial activity against $L$. (L.) major promastigotes using a fluorometric assay. Ciliatamides A (10) and B (11) showed $50 \%$ growth inhibition at $10.0 \mu \mathrm{g} / \mathrm{mL}$, but ciliatamide $C$ (12) was not active [77].

Valinomycin (13) is a cyclic depsipeptide isolated from Streptomyces sp. strains found in the Mediterranean sponges Axinella polypoides and Aplysina aerophoba. Valinomycin (13) displayed antiparasitic activity against $L$. (L.) major promastigotes $\left(\mathrm{EC}_{50}<0.11 \mu \mathrm{M}\right)$ and also exhibited cytotoxicity against 293T kidney epithelial cells $\left(\mathrm{EC}_{50}=11.24 \mu \mathrm{M}\right)$ and J774.1 macrophages $\left(\mathrm{EC}_{50}<0.10 \mu \mathrm{M}\right)$ [78].

The cyanobacterium Symploca sp. from Papua New Guinea yielded symplocamide A (14), which displayed activity against another protozoan parasite, Plasmodium falciparum; however, no activity against $L$. (L.) donovani promastigotes was observed up to $9.5 \mu \mathrm{M}$. A citrulline residue and a $\mathrm{N}, \mathrm{O}$-diMe-Br-Tyr moiety are unique structural features of symplocamide A [79].

Oscillatoria sp., a cyanobacterium from the Portobelo National Marine Park, yielded venturamide A (15) and B (16). Modified peptides 15 and 16 exhibited mild activity against $L$. (L.) donovani amastigotes, both with an $\mathrm{EC}_{50}$ of $19.0 \mu \mathrm{M}$ [80].

The glycoprotein pachymatismin was isolated from the sponge Pachymatisma johnstonii as a cytotoxic agent that was active against promastigotes of various Leishmania species and amastigotes of $L$. (L.) mexicana. Pachymatismin induced changes in Leishmania spp. cell shape, inhibited phospholipase A2 activity and decreased the invasion capacity. Every promastigote species 
that was tested was inhibited by pachymatismin with an $\mathrm{EC}_{50}$ value between 0.6 and $2.5 \mu \mathrm{g} / \mathrm{mL}$. Pachymatismin was also active against $L$. (L.) mexicana promastigotes between 1.0 and $1.2 \mu \mathrm{g} /$ $\mathrm{mL}$. In an attempt to evaluate the therapeutic potential of this glycoprotein, the effects on the amastigote stage of Leishmania spp. were studied. In acidic $\mathrm{pH}$, antileishmanial activity was obtained against axenic amastigotes at the same $\mathrm{EC}_{50}$ value [81].

\section{Terpenoids ( $\odot$ Figs. 3,4 and 5 )}

A series of terpenoids (17-29) was isolated from the sponges Spongia sp. and Ircinia sp. at the Turkish coastline of the Aegean Sea. Most of these terpenoids inhibited $L$. (L.) donovani (axenic amastigotes) growth. Among these compounds, 11 $\beta$-acetoxyspongi-12-en-16-one (28) had the most potent antileishmanial activity against $L$. (L.) donovani with an $\mathrm{EC}_{50}$ value of $0.75 \mu \mathrm{g} /$ $\mathrm{mL}$; this value is comparable to that of miltefosine $\left(\mathrm{EC}_{50}=\right.$ $0.20 \mu \mathrm{g} / \mathrm{mL}$ ). Unfortunately, however, the same compound showed almost identical cytotoxicity toward mammalian cells, indicating a lack of selectivity. Furospongin-1 (18) and 4-hydroxy-3-octaprenylbenzoic acid (23) also displayed antileishmanial activity with $\mathrm{EC}_{50}$ values of 4.80 and $5.60 \mu \mathrm{g} / \mathrm{mL}$, respectively. The remaining active compounds had moderate $\mathrm{EC}_{50}$ values ranging from $9.6 \mu \mathrm{g} / \mathrm{mL}$ to $18.9 \mu \mathrm{g} / \mathrm{mL}$. Compounds 17 and 18 are structurally very similar, with the exception that 18 contains an additional isoprene unit. The length of the isoprene chain appears to have no impact on the inhibition of $L$. (L.) donovani axenic amastigotes in culture. The remaining compounds had either low or no cytotoxic potential against mammalian cells $\left(\mathrm{EC}_{50}>90 \mu \mathrm{g} / \mathrm{mL}\right)[82]$.
Sesquiterpene $(S)-(+)$-curcuphenol (30), which was isolated from the Jamaican sponge Myrmekioderma styx, showed activity against several human cancer cell lines, in vitro antimicrobial activity, and antimalarial and antileishmanial activity against $L$. (L.) donovani promastigotes with an $\mathrm{EC}_{50}$ of $11.0 \mu \mathrm{M}$, which is similar to the $\mathrm{EC}_{50}$ of pentamidine and amphotericin $\mathrm{B}\left(\mathrm{EC}_{50}=4.7\right.$ and $1.2 \mu \mathrm{M}$, respectively) [83].

Holothurins A (31) and B (32) were isolated from the sea cucumber Actinopyga lecanora. Compound 31 showed moderate antiparasitic activity in vitro and in vivo against $L$. (L.) donovani. At $100.0 \mu \mathrm{g} / \mathrm{mL}$, holothurin A induced $73.2 \pm 6.8 \%$ and $66 \pm 6 \%$ inhibition in promastigotes and intracellular amastigotes, respectively. Holothurin A also displayed $44.6 \pm 10.6 \%$ inhibition of $L$. (L.) donovani at a dose of $100 \mathrm{mg} \cdot \mathrm{kg}^{-1} \cdot$ day $^{-1}$ after a 5 -day treatment of infected hamsters. Compound 32 inhibited promastigotes growth $82.5 \pm 11.6 \%$ and $47.3 \pm 6.5 \%$ at 100.0 and $50.0 \mu \mathrm{g} / \mathrm{mL}$, respectively. Holothurin B 32 also inhibited intracellular amastigotes $57.6 \pm 8.4 \%$ and $78 \pm 10 \%$ at 50.0 and $100.0 \mu \mathrm{g} / \mathrm{mL}$, respectively. In $L$. donovani-infected hamsters, holothurin B had a better activity profile $(71.5 \pm 12.8 \%$; $<<0.005)$ than holothurin $\mathrm{A}$, after a 5 -day treatment at $100 \mathrm{mg} \cdot \mathrm{kg}^{-1} \cdot$ day $^{-1}$ [84].

Pandaroside G (33) and its methyl ester pandaroside G (34) were isolated from the Caribbean sponge Pandaros acanthifolium. The glycosides 33 and 34 inhibited $L$. (L.) donovani (axenic amastigotes) growth with an $\mathrm{EC}_{50}$ of 1.3 and $0.051 \mu \mathrm{M}$, respectively. Compounds $\mathbf{3 3}$ and $\mathbf{3 4}$ appeared to be highly toxic against L6 cells, a primary cell line derived from mammalian (rat) skeletal myoblasts $\left(\mathrm{EC}_{50}=5.4\right.$ and $0.22 \mu \mathrm{M}$, respectively). Thus, 33 and 34 may be viable antiparasitic lead compounds [85].

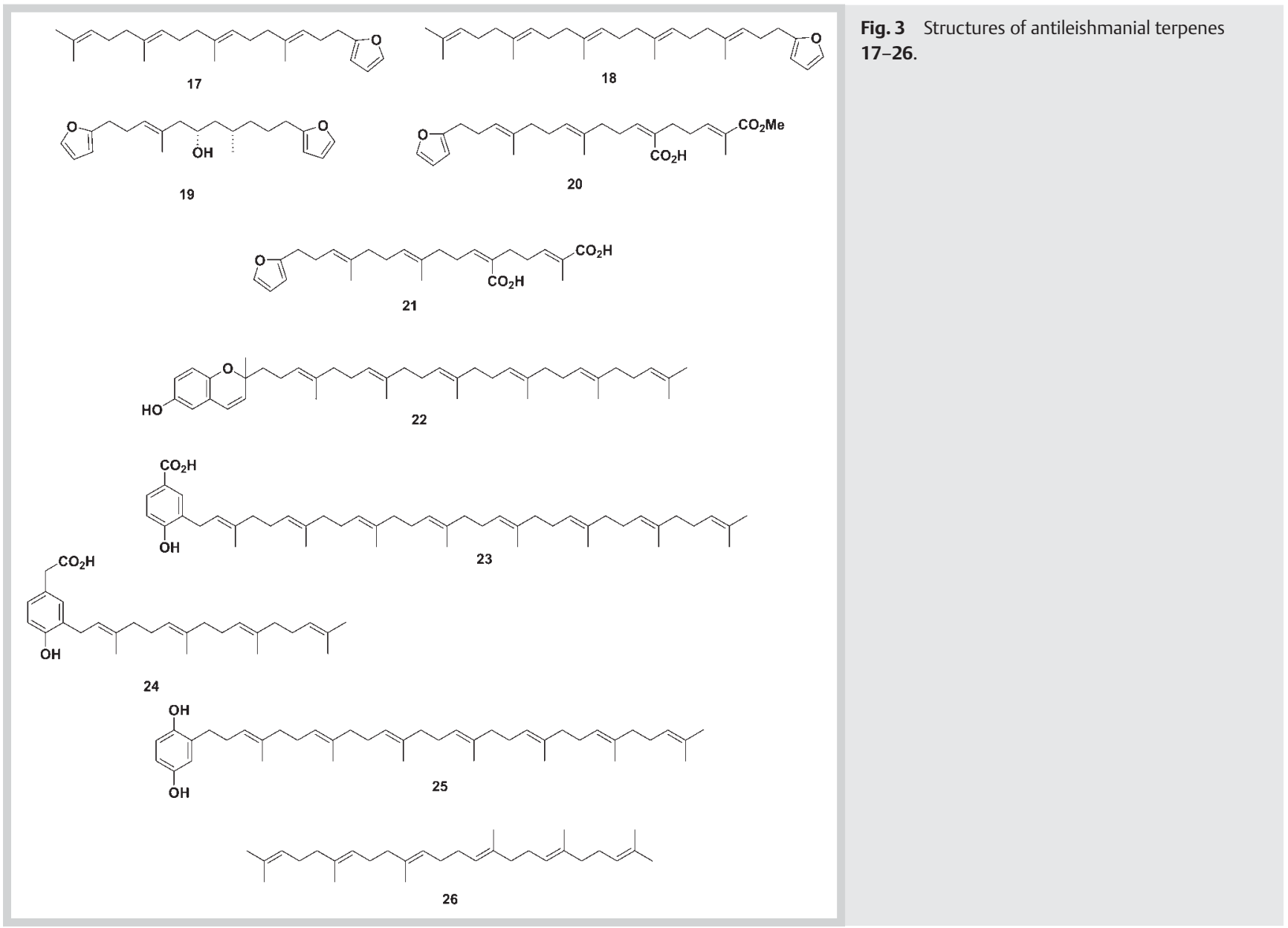




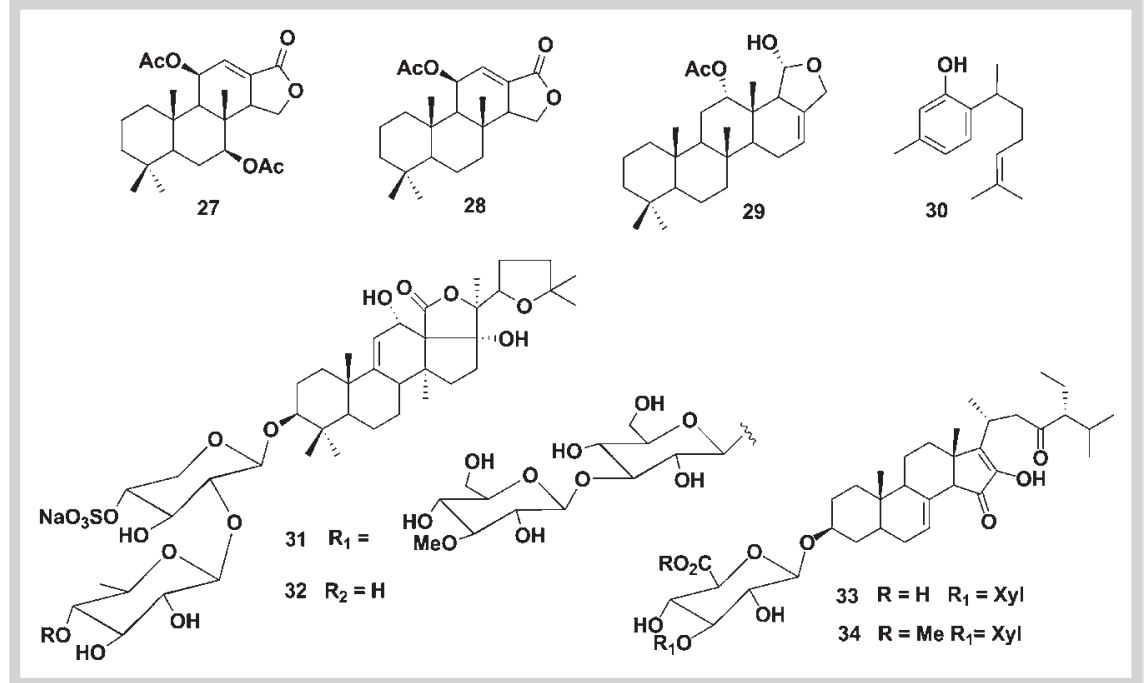

Fig. 4 Structures of antileishmanial terpenes 27-34.
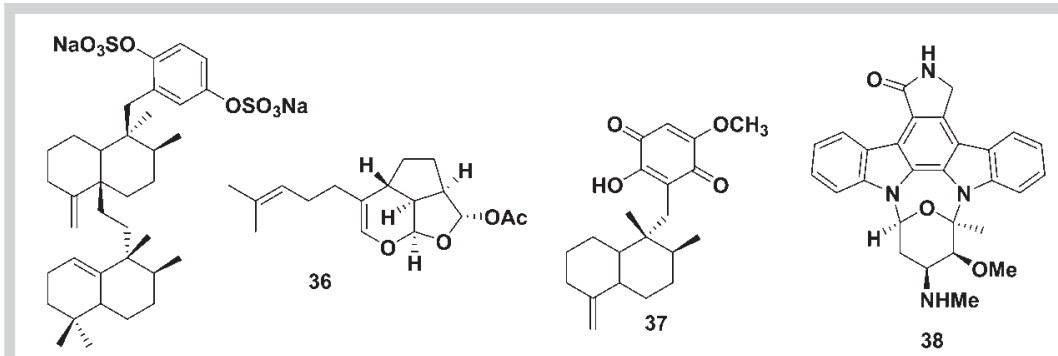

Fig. 5 Structures of antileishmanial terpenes 35-37 and antileishmanial alkaloids 38-53.

35<smiles>OCCc1c[nH]c2ccccc12</smiles>

39<smiles>CCCCC1c2nc(=N)[nH]c3c2C(CC3)CC1C</smiles><smiles>COc1cc2c(O)c3c1C(=NC=C2)C=CN3S</smiles><smiles>CCCCCC1CCCN2CC[C@H](C)O[C@@H]12</smiles>

40<smiles>CCCC[C@H]1C[C@H]2CCc3[nH]c(=N)nc(c32)[C@@]1(C)O</smiles>

41<smiles>CCCC[C@H](C)C1CC2CCc3[nH]c(=N)nc(c32)C1C</smiles>
42
The meroterpenoid isoakaterpin (35) was isolated from the Brazilian marine sponge Callyspongia sp. as an inhibitor of Leishmania tarentolae adenine phosphoribosyl transferase (L-APRT). This enzyme participates in the Leishmania spp. purine salvage pathway. Isoakaterpin (35) inhibited Leishmania tarentolae APRT with an $\mathrm{EC}_{50}$ of $1.05 \mu \mathrm{M}$, and it is the most potent known inhibitor of this enzyme [86].

The unique terpenoid euplotin C (36) was isolated from the marine ciliate Euplotes crassus. This is a relatively abundant compound, suggesting a possible ecological role in E. crassus. Euplotin 


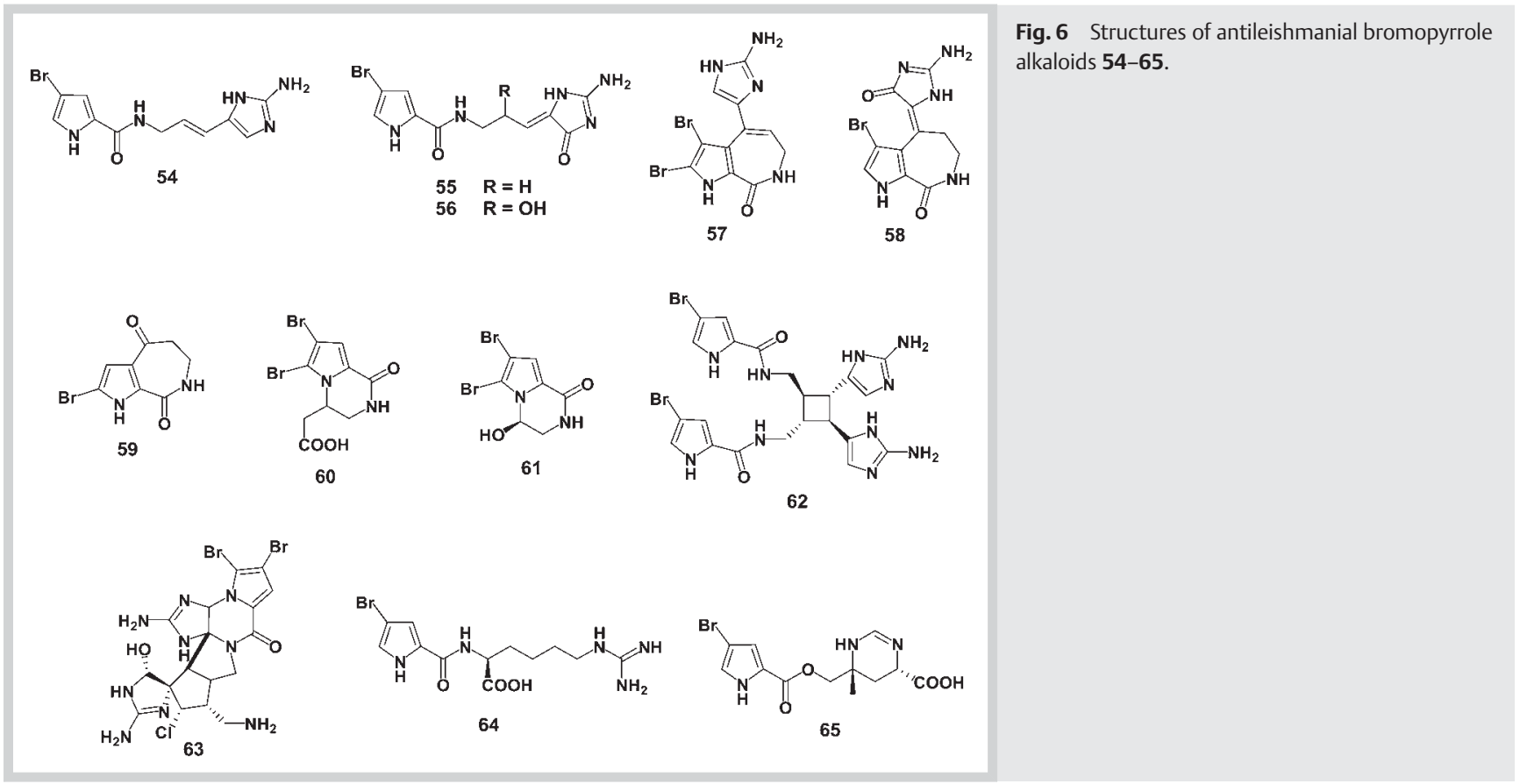

C (36) displayed antiparasitic activity to both promastigotes of $L$. (L.) major and $L$. (L.) infantum with $\mathrm{EC}_{50}$ values of 4.6 and $8.1 \mu \mathrm{g} /$ $\mathrm{mL}$, respectively. Leishmanicidal activity was also observed in the euplotin-producing cells of E. crassus when cultured with promastigotes; this activity increased in a time-dependent manner during a 6-h incubation. Euplotin $\mathrm{C}$ induced nonsignificant cytotoxicity $\left(\mathrm{EC}_{50}>200 \mu \mathrm{g} / \mathrm{mL}\right)$ against the $\mathrm{J774}$ cell line [87].

Ilimaquinone (37), isolated from the marine sponge Smenospongia sp., inhibited the $L$. (L.) mexicana promastigote growth. In addition, it induced promastigote morphological and ultrastructural changes. Comparison of the effects of ilimaquinone, ketoconazole, terbinafine, and dermaseptin on $L$. (L.) mexicana promastigotes showed that ilimaquinone activity was equivalent to that of terbinafine. Both compounds showed 100-fold less antiparasitic activity than ketoconazole. Dermaseptin has been shown to bind the surface of parasites and alter the lipid bilayer. Ilimaquinone (37) inhibited $L$. (L.) mexicana promastigote growth in a dose-dependent manner, killing $100 \%$ of parasites at $24 \mu \mathrm{M}$. The ilimaquinone $\mathrm{EC}_{50}$ was $5.6 \mu \mathrm{M}$, whereas the $\mathrm{EC}_{50}$ for terbinafine was $8.5 \mu \mathrm{M}$. Finally, the dermaseptin $\mathrm{EC}_{50}$ against promastigote growth was $3 \mu \mathrm{M}$. Ketoconazole completely lysed $L$. (L.) mexicana promastigotes at $0.06 \mu \mathrm{M}[88]$.

\section{Alkaloids ( $\odot$ Figs. 5 and 6 )}

Staurosporine (38), a well-known inhibitor of protein kinase C and platelet aggregation, was isolated from Streptomyces sp. strain 11 (GU214750) found in an unidentified Mediterranean sponge. Staurosporine was active against $L$. (L.) major promastigotes with an $\mathrm{EC}_{50}$ of $5.30 \mu \mathrm{M}$; however, it showed general cytotoxicity against $293 \mathrm{~T}$ kidney epithelial cells $\left(\mathrm{EC}_{50}=1.30 \mu \mathrm{M}\right)$ and J774.1 macrophages $\left(\mathrm{EC}_{50}<0.13 \mu \mathrm{M}\right)$ [78].

The indole alkaloid tryptophol (39), isolated from the marine sponges Spongia sp. and Ircinia sp. collected from the Turkish coastline of the Aegean Sea, was evaluated for in vitro activity against the mammalian stage of $L$. (L.) donovani (axenic amastigotes). This compound had an $\mathrm{EC}_{50}$ of $9.60 \mu \mathrm{g} / \mathrm{mL}$ and a low level of mammalian cell cytotoxicity $\left(\mathrm{EC}_{50}=63.46 \mu \mathrm{g} / \mathrm{mL}\right)$ [80].
The alkaloid araguspongin C (40), isolated from the marine sponge Haliclona exigua, moderately inhibited promastigote and intracellular amastigote growth at $100 \mu \mathrm{g} / \mathrm{mL}$. In addition, it had weak in vivo antileishmanial activity without inducing cytotoxic effects up to a concentration of $100 \mu \mathrm{g} / \mathrm{mL}[89,90]$.

Three tricyclic guanidine alkaloids, 1,8a;8b,3a-didehydro-8b-hydroxyptilocaulin (41), 1,8a;8b,3a-didehydro-8ahydroxyptilocaulin (42), and mirabilin B (43), were identified from the marine sponge Monanchora unguifera. Mirabilin B (43) was tested against $L$. (L.) donovani promastigotes and amastigotes, and presented an $\mathrm{EC}_{50}$ value of $17 \mu \mathrm{g} / \mathrm{mL}$ [91].

Bioassay-guided fractionation of extracts from the sponge Neopetrosia sp. yielded renieramycin A (44), which inhibited the viability of a recombinant $L$. (L.) amazonensis promastigote that expresses the enhanced green fluorescent protein La/egfp with an $\mathrm{EC}_{50}$ of $0.2 \mu \mathrm{g} / \mathrm{mL}$. Renieramycin A (44) was also cytotoxic against P388 murine leukaemia cells at a 10-fold higher concentration $\left(\mathrm{EC}_{50}=2.2 \mu \mathrm{g} / \mathrm{mL}\right)[92]$.

A series of ascididemin and pyridoacridine alkaloid derivatives have been tested against extracellular and intracellular $L$. (L.) donovani. Compound 45 (unnamed) displayed the most potent extracellular antiparasitic activity using promastigotes $\left(\mathrm{EC}_{50}=\right.$ $0.78 \mu \mathrm{g} / \mathrm{mL}$ ). Since the majority of the derivatives evaluated displayed significant in vitro cytotoxicity against RAW 264.7 cells, it was difficult to evaluate their activity against $L$. (L.) donovani amastigotes. Derivative $\mathbf{4 6}$ was the strongest inhibitor of intracellular $L$. (L.) donovani axenic amastigote viability $\left(\mathrm{EC}_{50}=35.0 \mu \mathrm{g} /\right.$ $\mathrm{mL}$ ) [93]. Isoaaptamine (47), which was isolated from an Aaptos sponge, is structurally related to $\mathbf{4 6}$ and displayed potent antileishmanial activity against $L$. (L.) donovani promastigotes $\left(\mathrm{EC}_{50}=0.7 \mu \mathrm{g} / \mathrm{mL}\right)$. Isoaaptamine was more active than both pentamidine $\left(\mathrm{EC}_{50}=1.6 \mu \mathrm{g} / \mathrm{mL}\right)$ and amphotericin $\mathrm{B}\left(\mathrm{EC}_{50}=1.1 \mu \mathrm{g} /\right.$ $\mathrm{mL}$ ), drugs which are currently used for leishmaniasis treatment. Moreover, isoaaptamine had no cytotoxicity against the Vero TC50 cell line [94]. Thus, the structure scaffolds of both 46 and 47 deserve further investigation for the development of antileishmanial agents. 
The common Indo-Pacific sponge Acanthostrongylophora sp. is a rich source of bioactive manzamine-related alkaloids. This class of alkaloids is known to display a number of potent biological activities, including cytotoxic, insecticidal, antibacterial, anti-inflammatory, anti-infective, and antiparasitic activities [95-97]. Several of such alkaloids displayed potent antiparasitic activity against $L$. (L.) donovani [95-98], including manzamine A (48), (+)-8-hydroxymanzamine A (49), manzamine $Y(50)$, manzamine $\mathrm{E}(51)$, 6-hydroxymanzamine $\mathrm{E}(52)$, and manzamine $\mathrm{F}(53)$. In tests using $L$. (L.) donovani promastigotes, manzamine A (48) displayed the most potent activity against viability ( 0 Table $\mathbf{1}$ ) [95, 97]. However, manzamine alkaloids also induce significant cytotoxicity in mammalian cells. Compounds $\mathbf{5 1}$ and $\mathbf{5 3}$ did not induce cytotoxicity at a concentration of $4.76 \mu \mathrm{g} / \mathrm{mL}[95,98]$.

The effects of bromopyrrole alkaloids 54-65, which are obtained from marine sponges belonging to the Axinella and Agelas genera, were evaluated in vitro against $L$. (L.) donovani (axenic amastigotes) and against $L 6$ cells. The majority of alkaloids induced $L$. (L.) donovani growth inhibition, particularly longamide B (60) $\left(\mathrm{EC}_{50}=3.85 \mu \mathrm{g} / \mathrm{mL}\right)$ and dibromopalau'amine $(63)\left(\mathrm{EC}_{50}\right.$ value $1.09 \mu \mathrm{g} / \mathrm{mL}$ ). The activity profiles of these compounds are quite remarkable; the effective concentration ranges on the same order of potency as the control compound, miltefosine $\left(\mathrm{EC}_{50}=0.21 \mu \mathrm{g} /\right.$ $\mathrm{mL})$. The other bromopyrrole alkaloids were much less active than 63 and 60, and dispacamide B (54), bromoaldisin (59), and longamide A (61) were completely inactive. When tested against mammalian (L6) cells, only dibromopalau'amine (63) and longamide $\mathrm{B}(\mathbf{6 0})$ induced toxicity $\left(\mathrm{EC}_{50}=4.46\right.$ and $9.94 \mu \mathrm{g} / \mathrm{mL}$, respectively) [99].

\section{Polyketides ( $\odot$ Fig. 7)}

The effects of pseudopyronines A (66) and B (67), which were isolated from fermentation extracts of Pseudomonas fluorescens, on the growth of $L$. $(L$.) donovani were evaluated as well as their cytotoxicity against the mammalian L6 and P388 cell lines. Pyrones (66) and (67) exhibited antiparasitic activity against $L$. (L.) donovani axenic amastigotes $\left(\mathrm{EC}_{50}=2.63\right.$ and $1.38 \mu \mathrm{g} / \mathrm{mL}$, respectively) and induced cytotoxicity in P388 leukaemia cells $\left(\mathrm{EC}_{50}=4.7\right.$ and $5.4 \mu \mathrm{g} / \mathrm{mL}$, respectively) at a lower concentration than against primary mammalian L6 cells $\left(\mathrm{EC}_{50}=23.2\right.$ and $17.9 \mu \mathrm{g}$ / $\mathrm{mL}$, respectively) [100].

Polyketides 68-72 isolated from the sponge Plakortis angulospiculatus from Brazil killed 100\% of $L$. (L.) chagasi promastigotes at a maximal concentration of $25 \mu \mathrm{g} / \mathrm{mL}$. These effects of polyketides 68-72 were dose-dependent with an $\mathrm{EC}_{50}$ value in the range of 1.9-8.5 $\mu \mathrm{g} / \mathrm{mL}$. Plakortide $\mathrm{P}(69)$ had the most effective antileishmanial activity $\left(\mathrm{EC}_{50}=1.9 \mu \mathrm{g} / \mathrm{mL}\right)$. Compounds $(68-72)$ were also submitted to an intracellular amastigote assay and demonstrated significant anti-amastigote and leishmanicidal activity $\left(\mathrm{EC}_{50}=0.50-3.40 \mu \mathrm{g} / \mathrm{mL}\right)$. Each compound $(68-72)$ tested also induced mammalian cytotoxicity in a dose-dependent manner $\left(\mathrm{EC}_{50}=16.6-31.6 \mu \mathrm{g} / \mathrm{mL}\right)[101]$.

The investigation of the antiparasitic effects of polyketides 68-72 was based on previous studies of the antiparasitic activity against $L$. (L.) mexicana reported for very similar polyketides, which were also isolated from Plakortis angulospiculatus. Among the polyketides 73-76, which are members of the plakortin family, (3S,6R,8S)-4,6-diethyl-3,6-epidioxy-8-methyldodeca-4-enoic acid (73) displayed the most potent activity $\left(\mathrm{EC}_{50}=0.29 \mu \mathrm{g} / \mathrm{mL}\right)$ and disrupted the $L$. (L.) mexicana promastigote cell membrane after 24-h treatment at a concentration of $1 \mu \mathrm{g} / \mathrm{mL}$. A significant decrease in parasite mobility was noted within 30 minutes after
Table 1 Antiparasitic activity of manzamine derivatives [95, 98].

\begin{tabular}{|c|c|c|c|}
\hline \multirow{2}{*}{$\begin{array}{l}\text { Manzamine } \\
\text { derivative }\end{array}$} & \multicolumn{2}{|c|}{ Leishmania (L.) donovani* } & \multirow{2}{*}{$\begin{array}{l}\text { Cytotoxicity } \\
\text { (Vero cells) } \\
\mathrm{EC}_{50}(\mu \mathrm{g} / \mathrm{mL} \text { ) }\end{array}$} \\
\hline & $\mathrm{EC}_{50}(\mu \mathrm{g} / \mathrm{mL})$ & $\mathrm{EC}_{90}(\mu \mathrm{g} / \mathrm{mL})$ & \\
\hline 48 & 0.9 & 1.8 & 1.2 \\
\hline 49 & 6.2 & 11 & 1.1 \\
\hline 50 & 1.6 & 8.0 & 3.9 \\
\hline 51 & 3.8 & 6.8 & n.c. \\
\hline 52 & 2.5 & 4.3 & 4.3 \\
\hline 53 & 4.2 & 7.0 & n.c. \\
\hline
\end{tabular}

* Promastigotes; n. c. $=$ no cytotoxicity

drug addition. Compound $74\left(\mathrm{EC}_{50}=1.0 \mu \mathrm{g} / \mathrm{mL}\right)$ was less effective, whereas the polyketides $\mathbf{7 5}$ and $\mathbf{7 6}$ showed similar activity but at higher doses ( $\mathrm{EC}_{50}=1.86$ and $2.7 \mu \mathrm{g} / \mathrm{mL}$, respectively) [102].

In addition, the antiparasitic polyketides gracilioethers A-C (7779) have been isolated from the sponge Agelas gracilis. Gracilioether B (78) inhibited $68 \%$ of $L$. major promastigote growth at $10 \mu \mathrm{g} / \mathrm{mL}$; however, no such activity was reported for compounds 77 and 79 [103].

\section{Xanthones (๑ Fig. 7)}

The marine-derived fungus Chaetomium sp. yielded chaetoxanthones A-C (80-82) and these compounds were tested against $L$. (L.) donovani intracellular amastigotes. Chaetoxanthone B (81) was active at an $\mathrm{EC}_{50}$ of $3.4 \mu \mathrm{g} / \mathrm{mL}$ and displayed no cytotoxicity against L6-cells $\left(\mathrm{EC}_{50}>90 \mu \mathrm{g} / \mathrm{mL}\right.$ ) or tumour cell lines (mean $\mathrm{EC}_{50}>10 \mu \mathrm{g} / \mathrm{mL}$ ). Chaetoxanthone C (82) was moderately active with an $\mathrm{EC}_{50}$ value of $3.1 \mu \mathrm{g} / \mathrm{mL}$, and cytotoxicity against $\mathrm{L} 6$ cells was not observed $\left(\mathrm{EC}_{50}=46.7 \mu \mathrm{g} / \mathrm{mL}\right)[104]$.

\section{Purines ( $\bullet$ Fig. 7)}

Agelasine $\mathrm{D}(\mathbf{8 3})$, isolated from the marine sponge Agelas sp., was tested against $L$. (L.) infantum amastigotes and for toxic effects against MRC-5 fibroblast cells. Compound (83) displayed weak in vitro activity against $L$. (L.) infantum with an $\mathrm{EC}_{50}$ value of $1.5 \mu \mathrm{g} /$ $\mathrm{mL}$ and induced toxic effects against MRC-5 cells $\left(\mathrm{EC}_{50}=6.7 \mu \mathrm{g} /\right.$ $\mathrm{mL})$ [105].

\section{Sterols (O Fig. 7)}

Isolated from the sponge Petromica ciocalyptoides, the steroid halistanol A (84) inhibited adenine phosphoribosyl transferase isolated from $L$. tarentolae (L-APRT) in a dose-dependent manner; $92 \%$ inhibition was observed at a concentration of $25 \mu \mathrm{g} / \mathrm{mL}$ $\left(\mathrm{EC}_{50}\right.$ of $\left.2.87 \mu \mathrm{g} / \mathrm{mL}\right)$. However, a desulphated derivative of $\mathbf{8 4} \mathrm{did}$ not inhibit L-APRT. Halistanol A (84) was also tested on the promastigotes of $L$. (L.) chagasi but did not show any antiparasitic activity [106].

24 -Ethyl-cholest-5 $\alpha$-7-en-3- $\beta$-ol (85) isolated from Agelas oroides inhibited $L$. (L.) donovani amastigotes with an $\mathrm{EC}_{50}$ of $29.5 \mu \mathrm{g} / \mathrm{mL}$ and induced cytotoxicity with an $\mathrm{EC}_{50}$ higher than $90 \mu \mathrm{g} / \mathrm{mL}$ in L6 cells [107]. Norselic acids A-E (86-90), isolated from the sponge Crella sp. from Antarctica, were also active against the Leishmania parasite. Each norselic acid was active against Leishmania sp. promastigotes at the following concentrations: $2.5 \mu \mathrm{M}$ for $\mathbf{8 6} ; 2.4 \mu \mathrm{M}$ for $\mathbf{8 7} ; 2.6 \mu \mathrm{M}$ for $\mathbf{8 8} ; 2.0 \mu \mathrm{M}$ for $\mathbf{8 9}$ and $3.6 \mu \mathrm{M}$ for 90 [108]. 


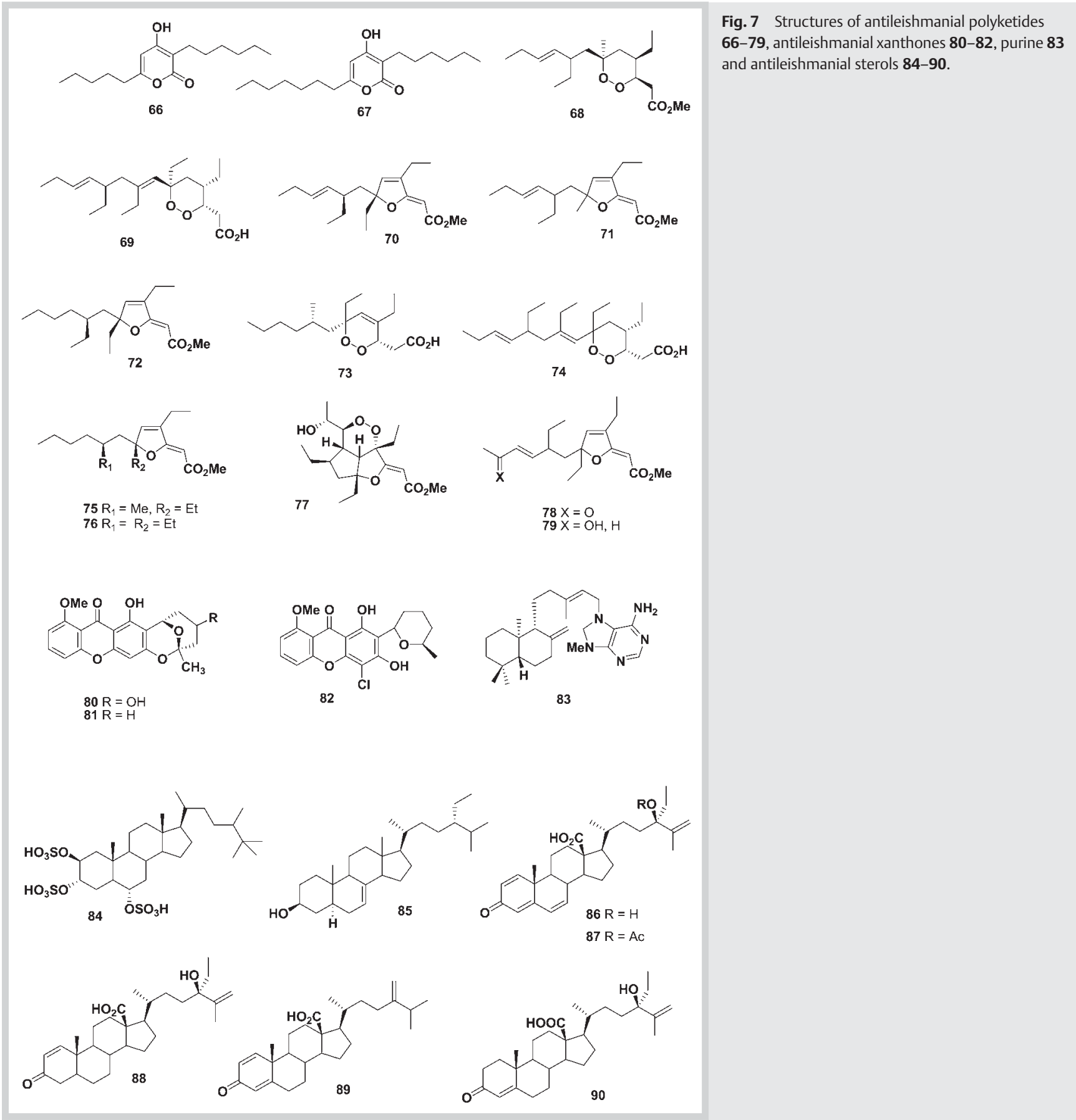

\section{Conclusion}

$\nabla$

There is a pressing need for inexpensive, rapid, and reproducible techniques to screen candidate compounds for the treatment of leishmaniasis. Without access to large libraries of compounds and without the collaborative work of multidisciplinary research groups, novel antileishmanial drugs are difficult to develop. Due to these factors, as well as the poor population that this disease affects, it is clear that big pharmaceutical companies will not include neglected parasitic diseases in their research programs. Therefore, major drug discovery efforts must come from academic research institutions.

Secondary metabolites isolated from both marine macro- and microorganisms are usually structurally complex and display po- tent biological activities. Since the pioneering discovery of the antileishmanial compound ilimaquinone (37) in 1997 [88] and of Plakortis polyketides in 1998 [102], several marine natural products have shown to inhibit several Leishmania strains. Considering that leishmaniasis is one of the major public health problems in developing countries, the discovery of these marine metabolites is very relevant to the search for novel antileishmanial chemotherapy.

Although modified peptides that were isolated from marine sources are very potent against Leishmania parasites, these compounds are not suitable as scaffolds for the development of drug leads because peptide synthesis is expensive and the active peptides are usually toxic and easily hydrolysed. A possible alternative to circumvent these limitations is the use of peptide mimet- 
ics to enhance compound bioavailability and stability under hydrolytic conditions. Of note is the discovery of the marine polyheteroaromatic alkaloid saponins and sterols as active cytotoxic agents against Leishmania spp. However, saponins are usually hemolytic. Thus, their use as a model for the development of antileishmanial drugs is very limited. On the other hand, several synthetic approaches have been developed for the production of polyheteroaromatic compounds and steroid derivatives. Therefore, it is possible to investigate the mode of action of such compounds in order to discover additional drug leads or novel cellular death routes in Leishmania sp. Finally, fermentation technologies are being used to discover antileishmanial agents from marine-derived microbial strains.

Undoubtedly, marine organisms are a very promising source of novel antileishmanial compounds, which can be further developed as drug prototypes for leishmaniasis treatment.

\section{Acknowledgements}

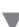

The authors thank the FAPESP BIOTA/BIOprospecTA funding program (grant 05/60175-2) for financial support to prepare this review.

\section{References}

1 World Health Organization. Leishmaniasis. Available at http://www. who.int/leishmaniasis/en/. Accessed November 22, 2010

2 Croft SL, Sundar S, Fairlamb AH. Drug resistance in leishmaniasis. Clin Microbiol Rev 2006; 19: 111-126

3 Janvier F, Morillon M, Olliaro P. Visceral leishmaniasis: clinical sensitivity and resistance to various therapeutic agents. Med Trop Mars 2008; 68: 89-101

4 Lukes J, Mauricio IL, Schonian G, Dujardin JC, Soteriadou K, Dedet JP, Kuhis K, Tintaya KW, Jirku M, Chocholova E, Haralambous C, Prationg $F$ Obornik M, Horak A, Ayala FJ, Miles MA. Evolutionary and geographical history of the Leishmania donovani complex with a revision of current taxonomy. Proc Natl Acad Sci USA 2007; 104: 9375-9380

5 Mauricio IL, Stothard JR, Miles MA. The strange case of Leishmania chagasi. Parasitol Today 2000; 16: 188-189

6 Berman J. Visceral leishmaniasis in the New World \& Africa. Indian J Med Res 2006; 123: 289-294

7 Lindoso JA, Lindoso AA. Neglected tropical diseases in Brazil. Rev Inst Med Trop Sao Paulo 2009; 51: 247-253

8 Rittig MG, Bogdan C. Leishmania-interaction: complexities and alternative views. Parasitol Today 2000; 16: 292-297

9 Mishra BB, Singh RK, Srivastava A, Tripathi VJ, Tiwari VK. Fighting against Leishmaniasis: search of alkaloids as future true potential anti-Leishmanial agents. Mini Rev Med Chem 2009; 9: 107-123

10 Frézard F, Demicheli C, Ribeiro RR. Pentavalent antimonials: new perspectives for old drugs. Molecules 2009; 30: 2317-2336

11 Mishra J, Saxena A, Singh S. Chemotherapy of leishmaniasis: past, present and future. Curr Med Chem 2007; 14: 1153-1169

12 Sundar S. Drug resistance in Indian visceral leishmaniasis. Trop Med Int Health 2001; 6: 849-854

13 Sundar S, Chatterjee M. Visceral leishmaniasis - current therapeutic modalities. Indian J Med Res 2006; 123: 345-352

14 Sundar S, Rosenkaimer F, Makharia MK, Goyal AK, Mandal AK, Voss A, Hilgard $P$, Murray HW. Trial of oral miltefosine for visceral leishmaniasis. Lancet 1998; 352: 1821-1823

15 van Griensven J, Balasegaram M, Meheus F, Alvar J, Lynen L, Boelaert M. Combination therapy for visceral leishmaniasis. Lancet Infect Dis 2010; 10: $184-194$

16 Sundar S, Rai M, Chakravarty J, Agarwal D, Agrawal N, Vaillant M, Olliaro $P$, Murray HW. New treatment approach in Indian visceral leishmaniasis: single-dose liposomal amphotericin B followed by short-course oral miltefosine. Clin Infect Dis 2008; 47: 1000-1006

17 Bhattacharya SK, Sinha PK, Sundar S, Thakur CP, Jha TK, Pandey K, Das VR, Kumar N, Lal C, Verma N, Singh VP, Ranjan A, Verma RB, Anders G, Sindermann H, Ganguly NK. Phase IV trial of miltefosine in the treatment of Indian visceral leishmaniasis. J Infect Dis 2007; 196: 591-598
18 Soto J, Arana BA, Toledo J, Rizzo N, Vega JC, Diaz A. Miltefosine for new world cutaneous leishmaniasis. Clin Infect Dis 2004; 38: 1266-1272

19 Bryceson A. A policy for leishmaniasis with respect to the prevention and control of drug resistance. Trop Med Int Health 2001; 6: 928-934

20 Chappuis F, Sundar S, Hailu A, Ghalib H, Rijal S, Peeling RW, Alvar J, Boelaert $M$. Visceral leishmaniasis: what are the needs for diagnosis, treatment and control? Nat Rev Microbiol 2007; 5: 873-882

21 Jha TK, Olliaro P, Thakur CP, Kanyok TP, Singhania BL, Singh NK, Akhoury $S$, Jha S. Randomised controlled trial of aminosidine (paromomycin) $v$ sodium stibogluconate for treating visceral leishmaniasis in North Bihar, India. BMJ 1998; 316: 1200-1205

22 Coimbra ES, Libong D, Cojean S, Saint-Pierre-Chazalet M, Solgadi A, Le Moyec L, Duenas-Romero AM, Chaminade P, Loiseau PM. Mechanism of interaction of sitamaquine with Leishmania donovani. J Antimicrob Chemother 2010; 65: 2548-2555

23 Dietze R, Carvalho SF, Valli LC, Berman J, Brewer T, Milhous W, Sanchez J, Schuster B, Grogl M. Phase 2 trial of WR6026, an orally administered 8aminoquinoline, in the treatment of visceral leishmaniasis caused by Leishmania chagasi. Am J Trop Med Hyg 2001; 65: 685-689

24 Jha TK, Sundar S, Thakur CP, Felton JM, Sabin AJ, Horton J. A phase II dose-ranging study of sitamaquine for the treatment of visceral leishmaniasis in India. Am J Trop Med Hyg 2005; 73: 1005-1011

25 Lima EB. Tratamento da leishmaniose tegumentar Americana. An Bras Dermatol 2007; 82: 111-124

26 Grecco SS, Reimão JQ Tempone AG, Sartorelli P, Romoff P, Ferreira MJ, Fávero $\mathrm{OA}$, Lago JH. Isolation of an antileishmanial and antitrypanosomal flavanone from the leaves of Baccharis retusa DC. (Asteraceae). Parasitol Res 2010; 106: 1245-1248

27 Tempone AG, Sartorelli P, Teixeira D, Prado FO, Calixto IA, Lorenzi H, Melhem MS. Brazilian flora extracts as source of novel antileishmanial and antifungal compounds. Mem Inst Oswaldo Cruz 2008; 103: 443-449

28 Tempone AG, Pimenta DC, Lebrun I, Sartorelli P, Taniwaki NN, de Andrade Jr HF, Antoniazzi MM, Jared C. Antileishmanial and antitrypanosomal activity of bufadienolides isolated from the toad Rhinella jimi parotoid macrogland secretion. Toxicon 2008; 52: 13-21

29 Muzitano MF, Falcão CA, Cruz EA, Bergonzi MC, Bilia AR, Vincieri FF, Rossi-Bergmann B, Costa SS. Oral metabolism and efficacy of Kalanchoe pinnata flavonoids in a murine model of cutaneous leishmaniasis. Planta Med 2009; 75: 307-311

30 Copp BR, Kayser O, Brun R, Kiderlen AF. Antiparasitic activity of marine pyridoacridone alkaloids related to the ascididemins. Planta Med 2003; 69: 527-531

31 Tada H, Shiho O, Kuroshima K, Koyama M, Tsukamoto K. An improved colorimetric assay for interleukin 2. J Immunol Methods 1986; 93: 157-165

32 Ganguly S, Bandyopadhyay S, Sarkar A, Chatterjee M. Development of a semiautomated colorimetric assay for screening anti-leishmanial agents. J Microbiol Methods 2005; 66: 78-86

33 Sereno D, Lemesre JL. Axenically cultured amastigote forms as an in vitro model for investigation of antileishmanial agents. Antimicrob Agents Chemother 1997; 41: 972-976

34 Mikus J, Steverding D. A simple colorimetric method to screen drug cytotoxicity against Leishmania using the dye Alamar Blue. Parasitol Int 2000; 48: 265-269

35 Callahan HL, Portal AC, Devereaux R, Grögl M. An axenic amastigotesystem for drug screening. Antimicrob Agents Chemother 1997; 41: 818822

36 Ephros $M$, Waldman E, Zilberstein $D$. Pentostam induces resistance to antimony and the preservative chlorocresol in Leishmania donovani promastigotes and axenically grown amastigotes. Antimicrob Agents Chemother 1997; 41: 1064-1068

37 Sereno D, Alegre AM, Silvestre R, Vergnes B, Ouaissi A. In vitro antileishmanial activity of nicotinamide. Antimicrob Agents Chemother 2005; 49: 808-812

38 Vergnes B, Vanhille L, Ouaissi A, Sereno D. Stage-specific antileishmanial activity of an inhibitor of SIR2 histone deacetylase. Acta Trop 2005; 94: 107-115

39 Sereno D, Cordeiro da Silva A, Mathieu-Daude F, Ouaissi A. Advances and perspectives in Leishmania cell based drug-screening procedures. Parasitol Int 2007; 56: 3-7

40 Seifert K, Escobar P, Croft SL. In vitro activity of anti-leishmanial drugs against Leishmania donovani is host cell dependent. J Antimicrob Chemother 2010; 65: 508-511 
41 Kram D, Thäle C, Kolodziej H, Kiderlen AF. Intracellular parasite kill: flow cytometry and NO detection for rapid discrimination between antileishmanial activity and macrophage activation. J Immunol Methods 2008; 20: 79-88

42 Wanderley JL, Benjamin A, Real F, Bonomo A, Moreira ME, Barcinski MA. Apoptotic mimicry: an altruistic behavior in host/Leishmania interplay. Braz J Med Biol Res 2005; 38: 807-812

43 de Freitas Balanco JM, Moreira ME, Bonomo A, Bozza PT, AmaranteMendes G, Pirmez C, Barcinski MA. Apoptotic mimicry by an obligate intracellular parasite downregulates macrophage microbicidal activity. Curr Biol 2001; 27: 1870-1873

44 Giudice A, Camada I, Leopoldo PT, Pereira JM, Riley LW, Wilson ME, Ho JL, de Jesus AR, Carvalho EM, Almeida RP. Resistance of Leishmania (Leishmania) amazonensis and Leishmania (Viannia) braziliensis to nitric oxide correlates with disease severity in Tegumentary Leishmaniasis. BMC Infect Dis 2007; 22: 7-10

45 Morais-Teixeira E, Carvalho AS, Costa JC, Duarte SL, Mendonça JS, Boechat $N$, Rabello $A$. In vitro and in vivo activity of meglumine antimoniate produced at Farmanguinhos-Fiocruz, Brazil, against Leishmania (Leishmania) amazonensis, $L$ (L.) chagasi and L (Viannia) braziliensis. Mem Inst Oswaldo Cruz 2008; 103: 358-362

46 Collins LA, Torrero MN, Franzblau SG. Green fluorescent protein reporter microplate assay for high-throughput screening of compounds against Mycobacterium tuberculosis. Antimicrob Agents Chemother 1998; 42: 344-347

47 Jacobs Jr WR, Barletta RG, Udani R, Chan J, Kalkut G, Sosne G, Kieser T, Sarkis GJ, Hatfull GF, Bloom BR. Rapid assessment of drug susceptibilities of Mycobacterium tuberculosis by means of luciferase reporter phages. Science 1993; 260: 819-822

48 Buckner FS, Verlinde CL, La Flamme AC, Van Voorhis WC. Efficient technique for screening drugs for activity against Trypanosoma cruzi using parasites expressing $\beta$-galactosidase. Antimicrob Agents Chemother 1996; 40: 2592-2597

49 Mc Fadden DC, Seeber F, Boothroyd JC. Use of Toxoplasma gondii expressing $\beta$-galactosidase for colorimetric assessment of drug activity in vitro. Antimicrob Agents Chemother 1997; 41: 1849-1853

50 Naylor LH. Reporter gene technology: the future looks bright. Biochem Pharmacol 1999; 58: 749-757

51 Lang T, Goyard S, Lebastard M, Milon G. Bioluminescent Leishmania expressing luciferase for rapid and high throughput screening of drugs acting on amastigote-harbouring macrophages and for quantitative real-time monitoring of parasitism features in living mice. Cell Microbiol 2005; 7: 383-392

52 Dube A, Gupta R, Singh N. Reporter genes facilitating discovery of drugs targeting protozoan parasites. Trends Parasitol 2009; 25: 432-439

53 Tsien RY. Green fluorescent protein. Annu Rev Biochem 1998; 67: 509544

54 Kain SR. Green fluorescent protein (GFP): applications in cell-based assays for drug discovery. Drug Discov Today 1999; 4: 304-312

55 Singh N, Dube A. Fluorescent Leishmania: applications to antileishmanial drug testing. Am J Trop Med Hyg 2004; 71: 400-402

56 Okuno T, Goto Y, Matsumoto Y, Otsuka H, Matsumoto Y. Applications of recombinant Leishmania amazonensis expressing egfp or the betagalactosidase gene for drug screening and histopathological analysis. Exp Anim 2003; 52: 109-118

57 Campbell RE. Realization of $\beta$-lactamase as a versatile fluorogenic reporter. Trends Biotechnol 2005; 22: 208-211

58 Buckner FS, Wilson AJ. Colorimetric assay for screening compounds against Leishmania amastigotes grown in macrophages. Am J Trop Med Hyg 2005; 72: 600-605

59 Sutcliffe JG. Nucleotide sequence of the ampicillin resistance gene of Escherichia coli plasmid pBR322. Proc Natl Acad Sci USA 1978; 75 : 3737-3741

60 Moore JT, Davis ST, Dev IK. The development of betalactamase as a highly versatile genetic reporter for eukaryotic cells. Anal Biochem 1997; 247: 203-209

61 Messaritakis I, Mazeris A, Koutala E, Antoniou M. Leishmania donovani s.l.: evaluation of the proliferation potential of promastigotes using CFSE stainin and flow cytometry. Exp Parasitol 2010; 125: 384-388

62 Garner DL, Johnson LA, Yue ST, Roth BL, Haugland RP. Dual DNA staining assessment of bovine sperm viability using SYBR-14 and propidium iodide. J Androl 1994; 15: 620-629

63 Abdullah SM, Flath B, Presber HW. Comparison of different staining procedures for the flow cytometric analysis of U-937 cells infected with different Leishmania-species. J Microbiol Methods 1999; 37: 123-138
64 Handman E, Spira DT. Growth of Leishmania amastigotes in macrophages from normal and immune mice. Z Parasitenkd 1977; 25: 75-81

65 Ghosh AK, Bhattacharyya FK, Ghosh DK. Leishmania donovani: amastigote inhibition and mode of action of berberine. Exp Parasitol 1985; 60: 404-413

66 Bodley AL, McGarry MW, Shapiro TA. Drug cytotoxicity assay for African trypanosomes and Leishmania species. J Infect Dis 1995; 172: 11571159

67 Macarron $R$. Critical review of the role of HTS in drug discovery. Drug Discov Today 2006; 11: 277-279

68 Mayr LM, Bojanic D. Novel trends in high-throughput screening. Curr Opin Pharmacol 2009; 9: 580-588

69 Croft SL, Coombs GH. Leishmaniasis-current chemotherapy and recent advances in the search for novel drugs. Trends Parasitol 2003; 19: 502 508

70 Lackovic K, Parisot JP, Sleebs N, Baell JB, Debien L, Watson KG, Curtis JM, Handman E, Street IP, Kedzierski L. Inhibitors of Leishmania GDP-mannose pyrophosphorylase identified by high-throughput screening of small-molecule chemical library. Antimicrob Agents Chemother 2010; 54: 1712-1719

71 Blunt JW, Copp BR, Munro MHG, Northcote PT, Prinsep MR. Marine natural products. Nat Prod Rep 2010; 27: 165-237

72 Sanchez LM, Lopez D, Vesely BA, Togna GT, Gerwick WH, Kyle DE, Linington $R G$. Almiramides A-C: discovery and development of a new class of Leishmaniasis lead compounds. J Med Chem 2010; 53: 4187-4197

73 Balunas MJ, Linington RG, Tidgewell K, Fenner AM, Ureña LD, Togna GD, Kyle DE, Gerwick WH. Dragonamide E, a modified linear lipopeptide from Lyngbya majuscula with antileishmanial activity. J Nat Prod 2010; 73: 60-66

74 Simmons TL, Engene N, Ureña LD, Romero LI, Ortega-Barría E, Gerwick L, Gerwick WH. Viridamides A and B, lipodepsipeptides with antiprotozoal activity from the marine cyanobacterium Oscillatoria nigro-wiridis. J Nat Prod 2008; 71: 1544-1550

75 Linington RG, Benjamin RC, Trimble EE, Almanza A, Ureña LD, Kyle DE, Gerwick $W H$. Antimalarial peptides from marine cyanobacteria: isolation and structural elucidation of gallinamide A. J Nat Prod 2009; 72: $14-17$

76 Cruz LJ, Luque-Ortega JR, Rivas L, Albericio F. Kahalalide F, an antitumor depsipeptide in clinical trials, and its analogues as effective antileishmanial agents. Mol Pharm 2009; 6: 813-824

77 Nakao Y, Kawatsu S, Okamoto C, Okamoto M, Matsumoto Y, Matsunaga $S$, van Soest RW, Fusetani $N$. Ciliatamides A-C, bioactive lipopeptides from the deep-sea sponge Aaptos ciliata. J Nat Prod 2008; 71: 469-472

78 Pimentel-Elardo SM, Kozytska S, Bugni TS, Ireland CM, Moll H, Hentsche $U$. Anti-parasitic compounds from Streptomyces sp. strains isolated from Mediterranean sponges. Mar Drugs 2010; 8: 373-380

79 Linington RG, Edwards DJ, Shuman CF, McPhail KL, Matainaho T, Gerwick WH. Symplocamide A, a potent cytotoxin and chymotrypsin inhibitor from the marine cyanobacterium Symploca sp. J Nat Prod 2008; 71: 22-27

80 Linington RG, González J, Ureña LD, Romero LI, Ortega-Barría E, Gerwick $W H$. Venturamides A and B: antimalarial constituents of the Panamanian marine cyanobacterium Oscillatoria sp. J Nat Prod 2007; 70: 397 401

81 Le Pape P, Zidane M, Abdala H, Moré MT. A glycoprotein isolated from the sponge, Pachymatisma johnstonii, has anti-leishmanial activity. Cell Biol Int 2000; 24: 51-56

82 Orhan I, Sener B, Kaiser M, Brun R, Tasdemir D. Inhibitory activity of marine sponge-derived natural products against parasitic protozoa. Mar Drugs 2010; 8: 47-58

83 Gul W, Hammond NL, Yousaf M, Peng J, Holley A, Hamann MT. Chemical transformation and biological studies of marine sesquiterpene $(S)$ (+)-curcuphenol and its analogs. Biochim Biophys Acta 2007; 1770: 1513-1519

84 Singh N, Kumar R, Gupta S, Dube A, Lakshmi V. Antileishmanial activity "in vitro" and "in vivo" of constituents of sea cucumber Actinopyga lecanora. Parasitol Res 2008; 103: 351-354

85 Regalado EL, Tasdemir D, Kaiser M, Cachet N, Amade P, Thomas OP. Antiprotozoal steroidal saponins from the marine sponge Pandaros acanthifolium. J Nat Prod 2010; 73: 1404-1410

86 Gray CA, Lira SP, Silva M, Pimenta EF, Thiemann OH, Oliva GO, Hajdu E, Andersen RJ, Berlinck RGS. Sulfated meroterpenoids from the Brazilian sponge Callyspongia sp. are inhibitors of the antileishmaniasis target adenosine phosphoribosyl transferase. J Org Chem 2006; 71: 86858690 
87 Savoia D, Avanzini C, Allice T, Callone E, Guella G, Dini F. Antimicrobial activity of euplotin $c$, the sesquiterpene taxonomic marker from the marine ciliate Euplotes crassus. Antimicrob Agents Chemother 2004; 48: 3828-3833

88 Rangel HR, Dagger F, Compagnone RS. Antiproliferative effect of illimaquinone on Leishmania mexicana. Cell Biol Int 1997; 21: 337-339

89 Dube A, Singh N, Saxena A, Lakshmi V. Antileishmanial potential of a marine sponge, Haliclona exigua (Kirkpatrick) against experimental visceral leishmaniasis. Parasitol Res 2007; 101: 317-324

90 Mishra BB, Singh RK, Srivastava A, Tripathi VJ, Tiwari VK. Fighting against leishmaniasis: search of alkaloids as future true potential antileishmanial agents. Med Chem 2009; 9: 107-123

91 Hua HM, Peng J, Fronczek FR, Kelly M, Hamann MT. Crystallographic and NMR studies of antiinfective tricyclic guanidine alkaloids from the sponge Monanchora unguifera. Bioorg Med Chem 2004; 12: 64616464

92 Nakao Y, Shiroiwa T, Murayama S, Matsunaga S, Goto Y, Matsumoto Y, Fusetani $N$. Identification of renieramycin a as an antileishmanial substance in a marine sponge Neopetrosia sp. Mar Drugs 2004; 2: 55-62

93 Copp BR, Kayser O, Brun R, Kiderlen AF. Antiparasitic activity of marine pyridoacridone alkaloids related to the ascididemins. Planta Med 2003; 69: 527-531

94 Gul G, Hammond NL, Yousaf M, Bowling JJ, Schinazi RF, Wirtz SS, Andrews GC, Cuevas C, Hamann MT. Modification at the C9 position of the marine natural product isoaaptamine and the impact on HIV-1, mycobacterial, and tumor cell activity. Bioorg Med Chem 2006; 14: 8495-8505

95 Rao KV, Donia MS, Peng J, Garcia-Palomero E, Alonso D, Martinez A, Medina M, Franzblau SG, Tekwani BL, Khan SI, Wahyuono S, Willett KL, Hamann MT. Manzamine B and E and ircinal a related alkaloids from an indonesian Acanthostrongylophora sponge and their activity against infectious, tropical parasitic, and Alzheimer's diseases. J Nat Prod 2006; 69: 1034-1040

96 Shilabin AG, Kasanah N, Tekwani BL, Hamann MT. Kinetic studies and bioactivity of potential manzamine prodrugs. J Nat Prod 2008; 71: 1218-1221

97 Rao KV, Kasanah N, Wahyuono S, Tekwani BL, Schinazi RF, Hamann MT. Three new manzamine alkaloids from a common Indonesian sponge and their activity against infectious and tropical parasitic diseases. J Nat Prod 2004; 67: 1314-1318

98 Rao KV, Santarsiero BD, Mesecar AD, Schinazi RF, Tekwani BL, Hamann MT. New manzamine alkaloids with activity against infectious and tropical parasitic diseases from an Indonesian sponge. J Nat Prod 2003; 66: 823-828
99 Scala F, Fattorusso E, Menna M, Taglialatela-Scafati O, Tierney M, Kaiser $M$, Tasdemir D. Bromopyrrole alkaloids as lead compounds against protozoan parasites. Mar Drugs 2010; 8: 2162-2174

100 Giddens AC, Nielsen L, Boshoff HI, Tasdemir D, Perozzo R, Kaiser M, Wang F, Sacchettini IC, Copp BR. Natural product inhibitors of fatty acid biosynthesis: synthesis of the marine microbial metabolites pseudopyronines $\mathrm{A}$ and $\mathrm{B}$ and evaluation of their anti-infective activities. Tetrahedron 2008; 64: 1242-1249

101 Kossuga MH, Nascimento AM, Reimão JQ Tempone AG, Taniwaki NN, Veloso K, Ferreira AG, Cavalcanti BC, Pessoa C, Moraes MO, Mayer MAS, Hajdu E, Berlinck RGS. Antiparasitic, antineuroinflammatory, and cytotoxic polyketides from the marine sponge Plakortis angulospiculatus collected in Brazil. J Nat Prod 2008; 71: 334-339

102 Compagnone RS, Piña IC. Antileishmanial cyclic peroxides from the Palauan sponge Plakortis aff. angulospiculatus. Tetrahedron 1998; 54: 3057-3068

103 Ueoka R, Nakao Y, Kawatsu S, Yaegashi J, Matsumoto Y, Matsunaga S, Furihata $K$, van Soest $R W$, Fusetani N. Gracilioethers A-C, antimalarial metabolites from the marine sponge Agelas gracilis. J Org Chem 2009; 74: 4203-4207

104 Pontius A, Krick A, Kehraus S, Brun R, Konig GM. Antiprotozoal activities of heterocyclic-substituted xanthones from the marine-derived fungus Chaetomium sp. J Nat Prod 2008; 71: 1579-1584

105 Vik A, Proszenyák A, Vermeersch $M$, Cos P, Maes L, Gundersen $L L$. Screening of agelasine D and analogs for inhibitory activity against pathogenic protozoa; identification of hits for visceral leishmaniasis and chagas disease. Molecules 2009; 14: 279-288

106 Kossuga MH, Lira SP, Nascimento AM, Gambardella MTP, Berlinck RGS, Torres YR, Nascimento GFF, Pimenta EF, Silva M, Thiemann O, Oliva G, Tempone A, Melhem MSC, Souza AO. Isolamento e atividades biológicas de produtos naturais das esponjas Monanchora arbuscula, Aplysina sp., Petromica ciocalyptoides e Topsentia ophiraphidites, da ascídia Didemnum ligulum e do octocoral Carijoa riisei. QN 2007; 30: 11941202

107 Tasdemir D, Topaloglu B, Perozzo R, Brun R, O'Neill R, Carballeira NM, Zhang $X$, Tonge PJ, Linden A, Ruedi P. Marine natural products from the Turkish sponge Agelas oroides that inhibit the enoyl reductases from Plasmodium falciparum, Mycobacterium tuberculosis and Escherichia coli. Bioorg Med Chem 2007; 15: 6834-6845

108 Ma WS, Mutka T, Vesley B, Amsler MO, McClintock JB, Amsler CD, Perman JA, Singh MP, Maiese WM, Zaworotko MJ, Kyle DE, Baker BJ. Norselic acids A-E, highly oxidized anti-infective steroids that deter mesograzer predation, from the Antarctic sponge Crella sp. J Nat Prod 2009; $72:$ 1842-1846 